History of Europe

Seventeenth Century Europe

State, Conflict and the Social Order in Europe 1598-1700 
History of Europe

Published

Seventeenth Century Europe 1598-1700

Thomas Munck

Eighteenth Century Europe 1700-1789

Jeremy Black

Forthcoming

Early Medieval Europe 400-1000

Roger Collins

Medieval Europe 1000-1250

Randall Rogers

Sixteenth Century Europe 1500-1600

Richard Mackenney

Nineteenth Century Europe 1789-1914

Alan Sked

Twentieth Century Europe 1915-1986

Anthony Adamthwaite 
History of Europe

\section{Seventeenth Century Europe}

State, Conflict and the Social Order in Europe 1598-1700

Thomas Munck

Macmillan Education 
ISBN 978-0-333-28641-8 ISBN 978-1-349-20626-1 (eBook)

DOI 10.1007/978-1-349-20626-1

(C) Thomas Munck 1990

Softcover reprint of the hardcover 1st edition 1990

All rights reserved. For information, write:

Scholarly and Reference Division,

St. Martin's Press, Inc., 175 Fifth Avenue,

New York, N.Y. 10010

First published in the United States of America in 1990

ISBN 978-0-312-04011-6 cloth

ISBN 978-0-312-04012-3 paper

Library of Congress Cataloging-in-Publication Data

Munck, Thomas

Seventeenth century Europe : state, conflict, and the social order in Europe, 1598-1700 / Thomas Munck.

p. cm.-(History of Europe)

Includes bibliographical references.

ISBN 978-0-312-04011-6.-ISBN 978-0-312-04012-3 (pbk.)

1. Europe-History-17th century. I. Title. II. Series: History of Europe (St. Martin's Press)

D246.M86 1990

940.2'2- dc20 


\section{Contents}

Chronology of main events $1598-1700$ ix Acknowledgments $\quad$ xxi Introduction xxiii Maps $\quad \mathbf{x x x}$

\section{The Thirty Years War in the German lands 1}

The German lands before 1618

Bohemia and the Rhine (1617-28) 7

Christian IV, Gustav Adolf and Wallenstein (1625-30) 11

Gustav Adolf and Swedish grand designs (1629-34) 16

The elusiveness of peace (1634-48) 20

The consequences of war and peace 23

\section{Government in wartime Europe 31}

Tax collection and war 35

The restored monarchy and the Huguenots in France $\quad 39$

The indispensable first minister: Richelieu and

Louis XIII 43

Tension and revolt in France in the 1630s 45

Castile and the Spanish system 49

Olivares: integration or disintegration? 51

Sweden and the challenge of empire 56

Christian IV and 'elective absolutism' in Denmark 62

Crown and parliament in England 66

Charles I and the abandonment of consensus politics $\quad 70$

Scotland and the Long Parliament 74

3 The framework of life 81

Population and food supply 82

The demographic effects of disease $\quad 90$

The impact of war 94

Prices and wages $\quad 97$

The family 99

Occupations and wealth distribution 103

Social and geographic mobility 106 
4 Enterprise and profit 109

Finance 112

Industry and trade 115

Regions in the European economy: the Mediterranean recession 117

The growth of the north-west 121

The frontier in the east 128

The pre-industrial economy: the west and the Ottoman Empire 132

5 The structure of society: nobility and officeholders 137

Tradition and noble status 139

The 'crisis of the aristocracy' 145

The French nobility and the crown 148

Ennoblement and the sale of offices in the west 151

Titles and venality in Castile and England 155

Nobility and government service in central and northern Europe 158

The Polish and Russian elites 162

6 The structure of society: urban life 165

The smaller towns 169

Larger cities 175

Capital cities 178

The urban poor 181

Rioting and crime 185

Charitable responses to urban poverty $\quad 189$

Official urban poor relief 193

7 Provincial revolts, civil war and the 'crisis of the 17th century' 199

Liberty or noble anarchy: Poland and the east 203

Urban revolt and provincial secession: Spain and its territories in the 1640s 208

The Frondes: absolutism challenged? 212

The English civil wars and Scotland 216

Revolution and the search for stability in England 222

Non-violent 'crises' in the Scandinavian kingdoms 228

Ebb and flow of republicanism in the United Provinces 232

8 The structure of society: peasant and seigneur $\quad 237$

Serfdom in Muscovy 242

Conditions in east-central Europe $\quad 246$

Entrepreneurial land usage in central and western Europe 249 
Commercial farming in the Netherlands and England 253

Peasant, bondsman and labourer in western Europe 256

Peasant protest and state involvement 261

9 Beliefs, mentalités, knowledge and the printed text 269

Witch-hunting $\quad 272$

The struggle for minds 277

The printed word 285

Scepticism, Galileo and the expanding universe 290

Science and the commonwealth of learning 294

The search for perfect government 299

10 The arts, the value of creativity and the cost of appearances $\quad 305$

Popular culture $\quad 307$

Church music and the city public $\quad 310$

The visual arts and the Catholic church in Rome $\quad 315$

Buildings and symbols $\quad 322$

Princely and royal court environments 326

Public patronage and appreciation of the arts 334

11 Absolutism and the return of order after $1660 \quad 340$

The limitations of central government $\quad 342$

State regulation of trade and industry $\quad 347$

Military power and fiscal strain in the Habsburg lands and France $\quad 352$

Restructuring in Brandenburg-Prussia and Sweden 355

The 'political nation' and the Stuart monarchy 1600-88 359

Church policies and absolutism 365

12 Government and conflict in the later seventeenth century 371

Louis XIV and international conflict in Europe after $1660 \quad 372$

Commercial rivalry in Europe and overseas 377

Internal opposition and the state monopoly of violence 382

The image of power and the secular state 386

The receding eastern frontier: Russia 391

Conclusion 396

Notes $\quad 402$

Select bibliography $\quad 431$

Selective index 442 


\section{Chronology of Main Events 1598-1700}

\begin{tabular}{|c|c|}
\hline The West & C. \& N. Europe \\
\hline $\begin{array}{l}\text { 1598: Peace of Vervins } \\
\text { betw. France and } \\
\text { Spain; }\end{array}$ & $\begin{array}{l}\text { Swedes depose } \\
\text { Sigismund: Charles IX } \\
(-1611)\end{array}$ \\
\hline $\begin{array}{l}\text { Edict of Nantes } \\
\text { protects French } \\
\text { Huguenots; }\end{array}$ & \\
\hline $\begin{array}{l}\text { Philip III of Spain } \\
(-1621)\end{array}$ & \\
\hline $\begin{array}{l}\text { 1600: English E. India } \\
\text { Co. }\end{array}$ & $\begin{array}{l}\text { Giordano Bruno burnt } \\
\text { (Rome) }\end{array}$ \\
\hline
\end{tabular}

1602: Dutch E. India Co.

1603: Death of

Elizabeth I: Scottish James VI/I (-1625); Shakespeare: Hamlet

1605: Gunpowder plot in Westminster

1606: Papal interdict vs Venice
Caravaggio: Death of the Virgin

Habsburg peace with Turks; emperor Rudolf II (1576-1612) loses power to his brother Matthias

1607: Ulster Plantation begun;

Virginia founded

1608: Quebec founded by French
Occupation of Donauwörth by Maximilian of Bavaria (1597-1651); Monteverdi: Orfeo

Diet of Regensburg fails;

Protestant union formed
The East

Boris Godunov tsar $(-1605)$
Muscovy: Time of Troubles (-1613)

Bolotnikov revolt in Ukraine 


\section{The West}

1609: 12-year truce betw. Spain and Un. Provinces;

Moors expelled from Spain;

Amsterdam Exchange Bank

1610: Henry IV murdered: Louis XIII $(-1643)$ under regent Marie de Medici

1611: English authorised version of Bible

1613: Amsterdam Exchange

1614: Estates General called in France

1615: Dutch take Moluccas

1616: Death of Shakespeare and of Cervantes

1617: Regency in France terminated by force

1618: Synod of Dordrecht narrows Dutch church

\section{C. \& N. Europe}

Jülich-Cleves dispute;

Letter of Majesty issued to Bohemian

Protestants;

German Catholic

League formed

Frederick $\mathrm{V}$ elector in Palatinate;

Galileo uses telescope

Christian IV (1588-

1648) vs Sweden

(Kalmar war);

Gustav Adolf king of

Sweden (-1632);

Saxony: Johann Georg I (-1656)

Death of emperor Rudolf II: Matthias $(-1619)$

Peace betw. Denmark and Sweden at Knäröd;

Elector of

Brandenburg adopts

Calvinism

Tr. of Xanten splits Jülich and Cleves

\section{The East}

Swedes and Poles in Muscovy

Sigismund III (15871632) of Poland garrisons Moscow
Michael Romanov tsar $(-1645)$
P. of Stolbova between Sweden \& Muscovy;

Swedish-Polish war
Defenestration of Prague starts Bohemian war 


\begin{tabular}{|c|c|c|}
\hline The West & C. \& N. Europe & The East \\
\hline $\begin{array}{l}\text { 1619: Oldenbarneveldt } \\
\text { executed in The } \\
\text { Hague; }\end{array}$ & $\begin{array}{l}\text { Death of emperor } \\
\text { Matthias: Ferdinand II } \\
\text { (-1637); }\end{array}$ & $\begin{array}{l}\text { Bethlen Gabor } \\
\text { invades Hungary }\end{array}$ \\
\hline $\begin{array}{l}\text { Black slaves in } \mathrm{N} . \\
\text { America }\end{array}$ & $\begin{array}{l}\text { Hamburg Bank set up; } \\
\text { Andrea: Christianopolis }\end{array}$ & \\
\hline $\begin{array}{l}\text { 1620: Bacon: Novum } \\
\text { Organum; } \\
\text { Mayflower sails }\end{array}$ & $\begin{array}{l}\text { Battle of } \\
\text { White Mountain: } \\
\text { 'Winter King' loses } \\
\text { Bohemia }\end{array}$ & \\
\hline \multirow[t]{2}{*}{$\begin{array}{l}\text { 1621: Death of Philip } \\
\text { III: Philip IV (-1665) }\end{array}$} & $\begin{array}{l}\text { Empire heads for } \\
\text { financial chaos, } \\
\text { 'Kipper- und } \\
\text { Wipperzeit'; }\end{array}$ & \\
\hline & Swedes take Riga & \\
\hline $\begin{array}{l}\text { 1622: French peace } \\
\text { with Huguenots } \\
\text { (Montpellier); }\end{array}$ & $\begin{array}{l}\text { Re-catholicisation } \\
\text { begins in Habsburg } \\
\text { lands; }\end{array}$ & \\
\hline $\begin{array}{l}\text { Olivares first minister } \\
\text { in Madrid }(-1643)\end{array}$ & $\begin{array}{l}\text { Recurrent peasant } \\
\text { revolts }(-1627)\end{array}$ & \\
\hline 1623: & $\begin{array}{l}\text { Maffeo Barberini } \\
\text { elected pope Urban } \\
\text { VIII (-1644) }\end{array}$ & \\
\hline $\begin{array}{l}\text { 1624: Anglo-French } \\
\text { war; }\end{array}$ & $\begin{array}{l}\text { Monteverdi: } I l \\
\text { combattimento }\end{array}$ & \\
\hline \multicolumn{3}{|l|}{$\begin{array}{l}\text { Richelieu incr. } \\
\text { influential in French } \\
\text { govt }(-1642)\end{array}$} \\
\hline $\begin{array}{l}\text { 1625: Death of James } \\
\text { VI/I: Charles }\end{array}$ & $\begin{array}{l}\text { Wallenstein hired by } \\
\text { emperor; }\end{array}$ & \\
\hline $\begin{array}{l}\text { I (-1649); } \\
\text { Death of Maurits of } \\
\text { Orange, Dutch } \\
\text { surrender Breda; }\end{array}$ & $\begin{array}{l}\text { Christian IV intervenes } \\
\text { in Empire }(-1629)\end{array}$ & \\
\hline \multicolumn{3}{|l|}{$\begin{array}{l}\text { Grotius: De jure belli ac } \\
\text { pacis }\end{array}$} \\
\hline $\begin{array}{l}\text { 1627: Siege of La } \\
\text { Rochelle; }\end{array}$ & $\begin{array}{l}\text { Wallenstein and Tilly } \\
\text { extend imperial control }\end{array}$ & \\
\hline $\begin{array}{l}\text { War of Mantuan } \\
\text { succession }\end{array}$ & $\begin{array}{l}\text { north; } \\
\text { Swedish peasant revolt } \\
\text { (Dalarna) }\end{array}$ & \\
\hline
\end{tabular}




\begin{tabular}{|c|c|c|}
\hline The West & C. \& N. Europe & The East \\
\hline \multirow{2}{*}{$\begin{array}{l}\text { 1628: Duke of } \\
\text { Buckingham } \\
\text { assassinated; } \\
\text { Petition of Right; } \\
\text { Harvey: De motu } \\
\text { cordis }\end{array}$} & $\begin{array}{l}\text { Wallenstein 'general of } \\
\text { the Baltic Sea'; }\end{array}$ & \\
\hline & $\begin{array}{l}\text { Swedish control of } \\
\text { Baltic trade tightened }\end{array}$ & \\
\hline $\begin{array}{l}\text { 1629: Huguenots } \\
\text { accept durable peace at } \\
\text { Alais; }\end{array}$ & $\begin{array}{l}\text { Peace of Lübeck takes } \\
\text { Christian IV out of war; } \\
\text { Edict of Restitution }\end{array}$ & $\begin{array}{l}\text { Truce of Altmark betw. } \\
\text { Sweden and Poland }\end{array}$ \\
\hline \multicolumn{3}{|l|}{$\begin{array}{l}\text { Engl. parliament } \\
\text { dissolved }\end{array}$} \\
\hline $\begin{array}{l}\text { 1630: Day of Dupes in } \\
\text { Paris; }\end{array}$ & $\begin{array}{l}\text { Gustav Adolf enters } \\
\text { German war; }\end{array}$ & \\
\hline \multirow{2}{*}{$\begin{array}{l}\text { Rubens: Peace and } \\
\text { War }\end{array}$} & Wallenstein dismissed; & \\
\hline & $\begin{array}{l}\text { Plague virulent in } \\
\text { Europe }\end{array}$ & \\
\hline \multirow[t]{5}{*}{ 1631: Gazette de France } & $\begin{array}{l}\text { Magdeburg sacked by } \\
\text { Tilly; }\end{array}$ & \\
\hline & $\begin{array}{l}\text { Tr. of Bärwalde betw. } \\
\text { France and Sweden; }\end{array}$ & \\
\hline & Leipzig colloquium; & \\
\hline & $\begin{array}{l}\text { Swedish victory at } \\
\text { Breitenfeld; }\end{array}$ & \\
\hline & $\begin{array}{l}\text { Fall of Prague to von } \\
\text { Arnim }\end{array}$ & \\
\hline $\begin{array}{l}\text { 1632: Wentworth in } \\
\text { Ireland; }\end{array}$ & \multirow{2}{*}{$\begin{array}{l}\text { Gustav Adolf killed at } \\
\text { Lützen; Christina } \\
\text { queen (-1654), } \\
\text { Oxenstierna dominant } \\
\text { (-1644); }\end{array}$} & $\begin{array}{l}\text { Muscovy attacks } \\
\text { Poland; }\end{array}$ \\
\hline \multirow{2}{*}{$\begin{array}{l}\text { Major rebellions in } \\
\text { France continuing into } \\
\text { 1640s }\end{array}$} & & $\begin{array}{l}\text { Wladyslaw IV king of } \\
\text { Poland (-1644); }\end{array}$ \\
\hline & $\begin{array}{l}\text { Galileo: Dialogue, then } \\
\text { trial in Rome }\end{array}$ & $\begin{array}{l}\text { Muscovite expansion } \\
\text { into Siberia }\end{array}$ \\
\hline $\begin{array}{l}\text { 1633: Baptists in } \\
\text { England; }\end{array}$ & $\begin{array}{l}\text { Protestant league of } \\
\text { Heilbronn; }\end{array}$ & \\
\hline \multicolumn{3}{|l|}{$\begin{array}{l}\text { Charles I visits } \\
\text { Edinburgh }\end{array}$} \\
\hline $\begin{array}{l}\text { 1634: Ship-money first } \\
\text { collected in London }\end{array}$ & $\begin{array}{l}\text { Wallenstein again } \\
\text { dismissed, then } \\
\text { assassinated; }\end{array}$ & $\begin{array}{l}\text { Polish-Muscovite } \\
\text { peace }\end{array}$ \\
\hline
\end{tabular}




\section{The West \\ 1635: France and Spain at war (-1659); \\ Académie française set up}

1636: France invaded by Habsburg army

1637: Spain loses

Breda;

prayer book riots in

Scotland;

Descartes: Discourse on method

1638: National

Covenant in Scotland

1639: Spanish navy defeated by Dutch off Downs

1640: Revolts in Catalonia and Portugal;

Short and Long

Parliaments called in

England (Scots invasion)

1641: Irish rebellion;

Strafford beheaded in

London;

Grand Remonstrance

1642: Civil war in

England;

Death of Richelieu, Mazarin first minister;

Hobbes: De cive;

Rembrandt: Night

Watch

1643: Death of Louis

XIII: Louis XIV

$(-1715)$ under regency;

Spain defeated at

Rocroi;
C. \& N. Europe

The East

Protestant defeat at

Nördlingen;

Swedish Form of Govt

Peace of Prague betw.

emperor and Saxony;

Saxons defeated by Swedes at Wittstock

Ferdinand III emperor (-1657);

Public opera house

opens in Venice

Muscovite expedition through Siberia to Pacific
Frederick William

elector of

Brandenburg-Prussia

$(-1688)$ : peace with

Sweden
Danish-Swedish war $(-1645)$ 


\section{The West \\ Assembly of \\ Westminster \\ 1644: Engl. battle at Marston Moor}

1645: Cromwell wins at Naseby;

Laud beheaded

1646: End of first civil war in England (-1648)

1647: Willem II Dutch stadholder $(-1650)$

1648: Parl. of Paris starts Frondes (-1653); 2nd Engl. civil war: Pride's Purge of parliament

1649: Charles I beheaded;

Cromwell to Ireland, later also Scotland;

Leveller Third Agreement

1650: Dutch power struggle until Willem II d.: Joh. de Witt takes over $(-1672)$

1651: First Navigation Act;

Hobbes: Leviathan

1652: Anglo-Dutch war

1653: Barebones Parliament, Cromwell Lord Protector; Ormée (Bordeaux) ends, princes' Fronde collapses, Mazarin back from exile
C. \& N. Europe

The East

German peace conferences start in

Westphalia (-1648)

Pope Innocent X

(-1655)

Colloquy of Torun

Alexis tsar (-1676)
Revolt of Masaniello in Naples

Dutch-Spanish peace;

Prague taken by Swedes;

Peace of Westphalia;

Frederick III king of

Denmark (-1670)

European-wide harvest failures (-1652)

Sw. Estates in conflict
Jan II Kazimierz king of Poland (abdic. 1668);

Riots in Moscow, zemsky called

Russian Ulozheniye (law code)

\section{Irkutsk founded}

Imperial Diet reconvenes;

Swiss peasant revolt starts in Luzerne
Nikon's reforms of Russian Orth. church 


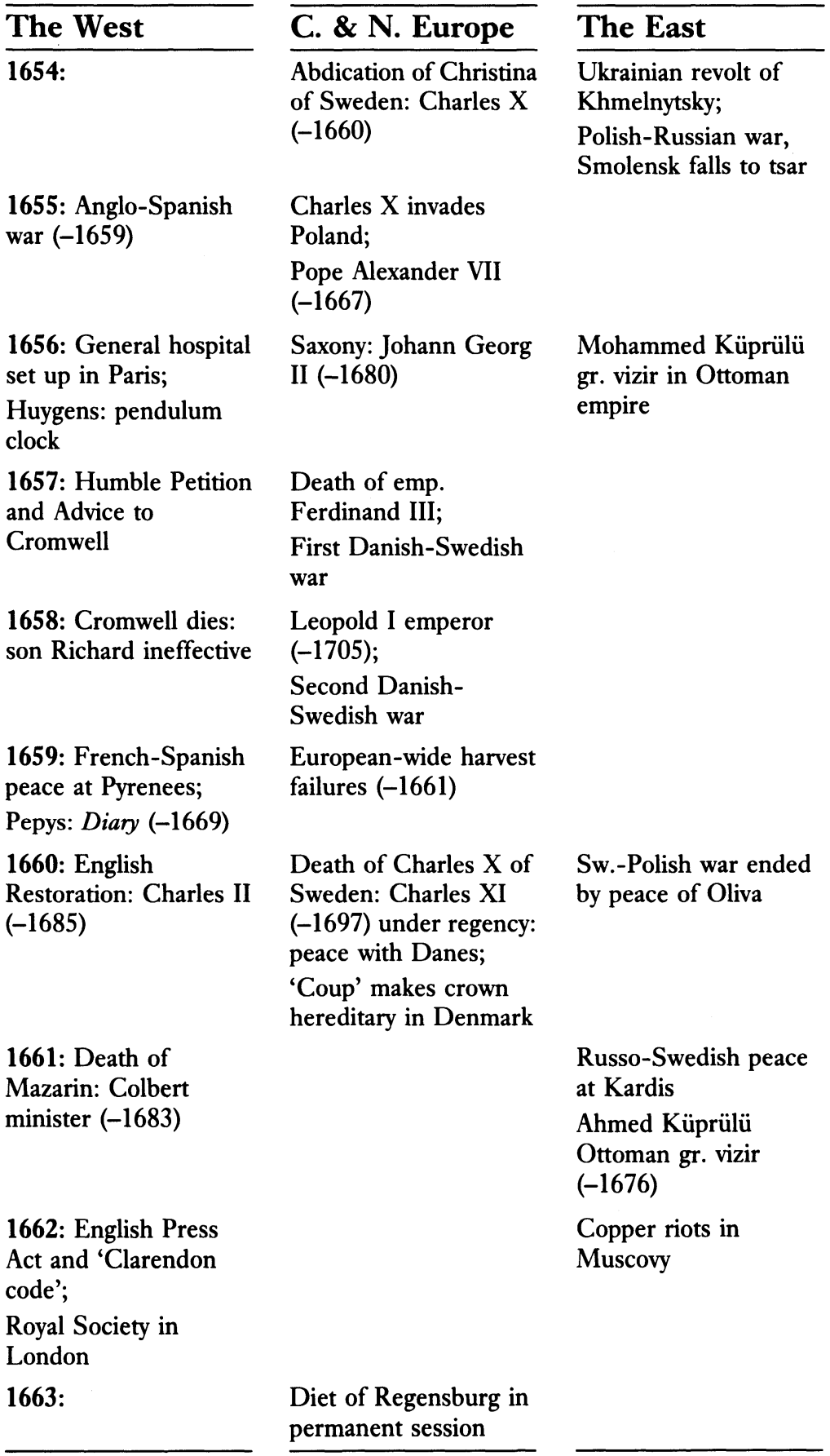




The West

1664: Anglo-Dutch war $(-1667)$

1665: London Plague;

Carlos II of Spain $(-1700)$

1666: Louvois min. of war;

Great Fire of London;

Molière: Misanthrope

1667: Milton: Paradise

Lost;

French war of Devolution in Flanders (-1668);

La Reynie chief of

Paris police

1668: Spanish partition tr;

Rembrandt: fewish

Bride

1670: Secret tr. of Dover;

Spinoza: Tractatus th.

1672: Franco-Dutch war (-1678): de Witt killed, power to William III of Orange; Stop of Engl. Exchequer 1673: Engl. Test Act passed

1674: P. of

Westminster: England out of war

1675: Rebuilding of St Pauls under way;

Revolt in Brittany crushed

1676:

\begin{tabular}{l}
\hline C. \& N. Europe \\
\hline Turkish-Habsburg \\
truce at Vasvar \\
Danish Royal Law
\end{tabular}

Schism in Russian Orth. church

Truce of Andrusovo betw. Poland and Muscovy;

Stenka Rasin rebellion
Grimmelshausen:

Simplicissimus

Death of Frederick III: Christian V (-1699)
Hungarian Wesselenyi revolt suppressed

Cossack-Turkish attack on Poland
Swedes invade $\mathrm{n}$.

Germany

Swedish defeat at

Fehrbellin;

Danish-Swedish war (-1679);

Fall of Griffenfeld (Denmark)

Pope Innocent XI $(-1689)$
John Sobieski king of Poland (-1696)
Fiodor III tsar (-1682) under regency;

Kara Mustafa gr. vizier 


The West

1677: William of Orange $\mathrm{m}$. Stuart princess Mary;

Spinoza: Ethics

1678: Peace of

Nijmegen ends war in west;

'Popish plot' in

England

1679: Habeas corpus

Act;

Engl. Exclusion Crisis;

Scottish Covenanters

defeated

1680: Réunions started on French Rhine

frontier;

Purcell: Dido ES Aeneas

1681: French seize

Strassburg

1682: Four articles launch Fr. church vs Papacy;

Fr. court to Versailles

1683: Franco-Spanish war;

Death of Colbert:

Louvois dominant

minister

1684: Truce at

Regensburg

1685: Death of Charles

II: James II/VII (-1688);

Argyll and Monmouth rebellions;

Revocation of Ed. of Nantes, Huguenot exodus from France

1686: League of Augsburg vs Louis XIV

\section{C. \& N. Europe}

\section{The East}

Russo-Turkish war $(-1681)$

Hamburg opera house

N. European wars end

Saxony: Johann Georg III (-1690)

Swedish comn.

examines regency:

crown strengthened;

Bohemian peasant revolt

Thököli rebellion in Hungary;

Swedish reduktion

under way

Siege of Vienna by

Turks fails;

Danish law code published
Peter I tsar (-1725), under Sofya's regency

Austro-Polish war vs Turks (-1699) 


\begin{tabular}{|c|c|c|}
\hline The West & C. \& N. Europe & The East \\
\hline $\begin{array}{l}\text { 1687: Louis } \\
\text { excommunicated; }\end{array}$ & $\begin{array}{l}\text { Turks defeated at } \\
\text { Mohacs; }\end{array}$ & \\
\hline Newton: Principia $M$. & $\begin{array}{l}\text { Habsburg control of } \\
\text { Hungary improved } \\
\text { (Diet of Pressburg) }\end{array}$ & \\
\hline $\begin{array}{l}\text { 1688: Fr. launch war of } \\
\text { League of Augsburg } \\
\text { (-1697); }\end{array}$ & $\begin{array}{l}\text { Frederick III elector of } \\
\text { Brandenburg-Prussia } \\
(-1713)\end{array}$ & Turks lose Belgrade \\
\hline \multicolumn{3}{|l|}{$\begin{array}{l}\text { William lands in } \\
\text { England, James flees to } \\
\text { France }\end{array}$} \\
\hline $\begin{array}{l}\text { 1689: William \& Mary } \\
\text { given Engl. crown: Bill } \\
\text { of Rights; }\end{array}$ & $\begin{array}{l}\text { French devastate } \\
\text { Palatinate }\end{array}$ & $\begin{array}{l}\text { Tsar Peter I takes } \\
\text { power }\end{array}$ \\
\hline \multicolumn{3}{|l|}{$\begin{array}{l}\text { Engl. join war on } \\
\text { France; }\end{array}$} \\
\hline \multicolumn{3}{|l|}{$\begin{array}{l}\text { Huguenot revolt in S. } \\
\text { France; }\end{array}$} \\
\hline \multicolumn{3}{|l|}{ James lands in Ireland; } \\
\hline \\
\hline $\begin{array}{l}\text { 1690: James defeated } \\
\text { at Boyne }\end{array}$ & & $\begin{array}{l}\text { Mustafa Küprülü leads } \\
\text { Ottoman recovery }\end{array}$ \\
\hline $\begin{array}{l}\text { 1691: Death of } \\
\text { Louvois }\end{array}$ & $\begin{array}{l}\text { Saxony: Johann Georg } \\
\text { IV (-1694) }\end{array}$ & \\
\hline $\begin{array}{l}\text { 1692: Massacre at } \\
\text { Glencoe }\end{array}$ & $\begin{array}{l}\text { Hannover becomes } \\
\text { electorate }\end{array}$ & \\
\hline $\begin{array}{l}\text { 1693: National debt set } \\
\text { up in England }\end{array}$ & $\begin{array}{l}\text { Swedish absolutism } \\
\text { complete }\end{array}$ & \\
\hline $\begin{array}{l}\text { 1694: Bank of } \\
\text { England; }\end{array}$ & $\begin{array}{l}\text { Saxony: Augustus the } \\
\text { Strong }(-1733) \text {; }\end{array}$ & \\
\hline $\begin{array}{l}\text { Famine starts in much } \\
\text { of Europe }(-1697)\end{array}$ & $\begin{array}{l}\text { Halle University } \\
\text { founded }\end{array}$ & \\
\hline \multicolumn{3}{|l|}{$\begin{array}{l}\text { 1695: End of effective } \\
\text { censorship in England }\end{array}$} \\
\hline $\begin{array}{l}\text { 1696: Bayle: Dict. } \\
\text { historique }\end{array}$ & & Peter takes Azov \\
\hline \multirow[t]{2}{*}{$\begin{array}{l}\text { 1697: Tr. of Rijswick } \\
\text { ends war in west }\end{array}$} & $\begin{array}{l}\text { Augustus also king of } \\
\text { Poland; }\end{array}$ & $\begin{array}{l}\text { Habsburg victory over } \\
\text { Turks (Zenta); }\end{array}$ \\
\hline & $\begin{array}{l}\text { Charles XII king of } \\
\text { Sweden }(-1718)\end{array}$ & Peter I visits west \\
\hline
\end{tabular}


Chronology of main events 1598-1700 xix

The West

1698: Spanish partition

tr.;

Fénelon: Télémaque

1699: Scottish Darien project fails;

Vauban: Dime royale

(not publ. yet)

1700: Spanish

Habsburg line extinct

\section{C. \& N. Europe}

The East

Streltsy revolt suppressed by Peter

P. of Karlowitz ends

Turkish war;

Frederick IV of

Denmark $(-1730)$

Great northern war

(-1721) 


\section{Acknowledgements}

This volume has taken much longer to write than originally anticipated, but in the process I have benefited from the help and advice of many. I owe most of all to my family - especially to my wife Margaret, who has not only for all her married life had to put up with someone perpetually reluctant to take a break from the current part of successive time-consuming projects, but has cheerfully encouraged and helped me along; and to my children, without whom this book would have appeared much sooner!

Any historian attempting a wide-ranging survey has an enormous debt to the countless scholars in whose work he has sought evidence, ideas and interpretative guidance - and whose findings he may in the process have been rash enough to compress out of recognition. There are some areas covered by this book where I have detailed research experience of my own, but many more where I have necessarily had to rely entirely on the work of others. The endnote references and the bibliography will, I hope, serve as some acknowledgement of where my greatest debts lie; but such is the vitality and range of work in the early modern period that neither of these can, within the confines of a textbook, be comprehensive. I have been able to include references only to what seemed to me most important and most helpful for anyone wishing to pursue particular themes in greater depth, but have added a number of works of a slightly more specialised nature, where more thorough guidance is given on recent developments in the field. If there is a heavy weighting towards work completed in the last ten or fifteen years, that is because perceptions of many central aspects of the period have in fact changed dramatically within that time-span.

I am grateful to the University of Glasgow for leaves of absence, and for providing what is still a congenial and stimulating environment for students and staff alike. Many colleagues and friends deserve personal acknowledgement, but I owe a particular debt to the following: to Hamish Scott at the University of St Andrews, whose detailed and invariably helpful comments were both a great encouragement when the enterprise seemed daunting, and of enormous practical assistance; and at my own university to Christopher F. Black and Alan G. R. Smith, whose expertise in areas outside my usual range proved particularly invaluable. For chapter $10 \mathrm{I}$ have unashamedly pirated ideas from a Special Subject which Chris Black and I have run jointly 
for some years, and his thorough knowledge of especially Roman Catholic Italy has been of as much benefit to me as to our students. No less generous with his time was G.V.R. Grant, always willing to help by commenting on drafts at any stage of the work. I need hardly say that these friends and colleagues, whilst generously spending much time and effort on improving both structure and detail, in no way take on any responsibility for inadequacies in the final text.

In a less direct but important way I have also gained a great deal from certain colleagues outside the field of early modern Europe; in particular, Evan Mawdsley and Rick Trainor, whose enthusiasm brought me into the age of the microcomputer, changing my outlook both on teaching and on research in the process. That this book shows so little obvious sign of quantitative analysis is something that I regret, but which the nature of the project made inevitable. At least its production was greatly eased (the excellent earlier typing of Pat Ferguson notwithstanding) by means of the new technology, which has also enabled me to remedy some of the accruing defects of long gestation. And on that note I must thank my publishers for their forbearance with more overshot deadlines than I would care to admit in print.

University of Glasgom

ThOMAS MUNCK

October 1988 


\section{Introduction}

No textbook on a whole century of European history could hope to be fully comprehensive, given the amount of stimulating work that is being done in the field of early modern studies. The structure of this book has accordingly been based on two broad principles. First, while the narrative framework is covered in some detail in the key political chapters of the book (namely the first two, the seventh and the last two), the rest of the text is centred on themes which are crucial to an understanding of the period but which do not necessarily lend themselves either to chronologically or to geographically structured treatment. The aim has been to survey areas where more recent work has led to reassessments of the period and its meaning, and to outline some of the ideas which have guided historians in their attempts to solve crucial difficulties. The index will help readers locate individuals and countries on which they may wish to concentrate; the book as a whole will, it is hoped, provide some guidance for those seeking an overall understanding of the relationship between state and subject, of the structure of society, of the location of power and the nature of status and influence, of the mental and cultural world of the early modern period, of the urban and rural communities, and of the demographic and economic realities that shaped society.

Second, the book has been written in the belief that the British Isles are part of Europe. This is not to say that English or Scottish developments are necessarily comparable to what happens on the continent: indeed one obvious thread running through this book is the significance of the local and the particular all over the continent, and the extent to which even smaller states in this period were still far from being coherent entities in themselves in any meaningful sense. But the fact that the British Isles were surrounded by sea, while ensuring a natural advantage in avoiding the worst excesses of continental military development, also ensured ready commercial, cultural and even political contact with continental states - despite that legendary streak of insularity and xenophobia for which at least the English were renowned. During the seventeenth century, as newspapers and travel made Europeans more aware of what was happening beyond their immediate horizons, some observers also became more aware of the potential repercussions of developments in other countries. Nowhere is this more strikingly revealed than in the horror all over the continent 
which greeted the news of the execution of Charles I, or in the growing awareness later in the century that Louis XIV was becoming both a model of the grandeur of monarchy and a warning of the dangers of military arrogance.

French and English material necessarily forms a large part of any survey of early modern Europe, partly because French and Englishlanguage scholars have led the way towards a re-evaluation of the social and economic history of the period. Given the strengths of recent publications in these fields, however, the aim of this book has been to try to broaden the perspective by emphasising central, northern and eastern Europe as far as possible. This may at times lead to some unusual choices of examples and case-studies; in the process, however, it is hoped that a more balanced view of European developments will emerge. Absolute monarchy, to return to an earlier point, may have had its most grandiose exponent in the form of Louis XIV; but it is the history of smaller states, as well as the reluctance of the English to follow suit, that throw the clearest light on what governments could and could not achieve in practice during this period.

The seventeenth century, as a period, itself requires some justification. It stands in transition between on the one hand the relatively prosperous and dynamic sixteenth century, with its major religious debates, its overseas expansion, and the economic growth which lasted into the 1590s or even to 1620; and on the other the more relaxed and expansive eighteenth century, where aristocratic society was at its height yet where many intellectual and cultural trends came to fruition in the enlightenment. Boxed in by the Moslem world in the Mediterranean, threatened by recurrent warfare both amongst the European powers and overseas, and at times overwhelmed by disease and starvation of extraordinary ferocity, seventeenth-century Europe was under siege. Chapter 7 is a central part of this story, covering the middle decades of the century when to many Europeans the whole structure seemed about to collapse. This chapter provides the resolution of the growing tensions of wartime Europe discussed in the first two chapters, but also helps to explain why those with any influence were so insistent after 1660 on the preservation of the social order and the consolidation of stable monarchy. This consolidation is discussed in chapter 11, whilst some of its negative sides, together with the continuing limitations of classic absolutism, are outlined in the last chapter.

Only rarely is the story taken beyond the last decade of the seventeenth century. This is a departure from some textbook norms, where 1715 has been the point of termination. I am not convinced that the latter date is helpful: by that stage the War of the Spanish Succession had drastically altered the balance of power in a way that belongs to the eighteenth century, not the seventeenth. No less 
important, many of the central themes of the seventeenth century reach a natural conclusion in the last years of the century rather than after an additional half-generation of European war: this applies to the witchcraze as well as to the completion of the scientific and intellectual revolutions, to the commercial reorientation of Europe in favour of the north-west, as well as to the resolution of the last trailers of the 'mid-century crisis' in England in 1688-89 and in Sweden in the period 1680-97. French absolutism itself makes best sense if seen as an organic development from the end of the civil war in 1598, through Henry IV and the ministers of Louis XIII, to a culmination (after the brief interlude of the Fronde) in the fully-developed but hardly innovative approach of Louis XIV's ministers Colbert and Louvois. In the last years of his reign, however, the French crown had to rely on emergency expedients, abandoning any long-term planning in favour of what at times seemed simple survival in an all-out European war. The legacy of those last years was apparent through much of the eighteenth century.

In the broader cultural area there are equally good reasons to stop short of the turn of the century. Chapter 10 attempts to analyse the period in terms of the arts. This discussion cannot be anything other than provisional, since in some areas research is still in its infancy. For that reason, too, some areas of Europe that might reasonably have deserved more prominent treatment are only covered in passing. However, the point of the chapter is not to attempt total coverage, since that is not yet possible, but instead to highlight some of the main concepts and problems that the historian faces in trying to integrate cultural history into a wider explanatory framework. The literary dimensions alone could easily have taken up all the available space; instead, however, analysis concentrates on areas where more reliable results can at this stage be attained, particularly with regard to music, the fine arts and architecture. In the arts, too - whether one examines the changes in literary tastes, away from the grandeur and passion of Milton and Racine towards the lighter entertainment of the Restoration theatre, or whether one turns from the dramatic masterpieces of Monteverdi to the conventionality of court music during the last years of Lully and after his death, or whether one looks at the relative decline of Italian artistic innovation after the age of Bernini - the conclusion must once more be that a natural point of summation comes in the last quarter of the seventeenth century. By then the demands of patrons and the tastes of the public were coming to favour the idyllic more than the dramatic or the emotional. By then, too, the new 'aristocratic' standards of the ancien régime were becoming apparent even in the paintings of the Dutch. Historians who have worked on the relationship between popular and elite culture also on the whole agree, as we shall see, that the signs of a divergence between 
the two become fully apparent only towards the end of the period.

In terms of the social history of the period, a century is perhaps less meaningful. Continuity is often more apparent than change, and the historian must try to avoid over-dramatising what is often a very gradual and almost imperceptible process. Nowhere is this more obvious than with respect to the peasantry and to peasant-seigneur relations. Nevertheless chapter 8 has been placed after that on the 'mid-century crisis' because the consolidation of serfdom in parts of eastern and east-central Europe clearly was in part conditioned by the resolution not just of the Thirty Years War but also of the bitter conflict in northern Europe and the Ukraine in the 1650s. In Poland, in particular, the crown then lost what with hindsight may have been its last chance of playing a decisive regulative role in the style of other European monarchies. As we shall note, it is simplistic to see rural Europe as divided into east and west, enserfed and 'free'; ultimately landowners had a natural interest in preserving the productive capacity of their peasants, even if they might interpret that interest in different ways. In the long-term perspective, peasant-seigneur relations formed an essential and fundamental part of the social hierarchy all over early modern Europe, and contemporaries recognised the mutual dependence that such a relationship involved. It is difficult to avoid the conclusion, however, that at some stage the market-orientation and exclusive privileges of some east-central European landowners would produce a fundamental divergence of approach from the more divided motivations of the western elite, concerned as they were with status based both on the rentier income of landed estates and on the juggling for position in the office-holding ranks of increasingly intricate bureaucracies and court circles.

At the beginning of the seventeenth century, a well-informed European would have had a very different perception of his political and social environment than that of his grandson or great-grandson after the peace settlements of 1648, 1659 and 1660. The Thirty Years War, for all its tortuous meanderings, had inescapable and decisive consequences everywhere - not just in central Europe but also, as even the sheer length of chapter 2 suggests, on every part of the continent. The slowness with which the conflict got off the ground, however, suggests that 1618 did not mark the culminating release of long-accumulating tensions and imbalances in Europe. On the contrary, one could argue that at the turn of the century the outlook was in some respects quite positive.

On the economic front, despite the catastrophic harvest failures and consequent unrest of the $1590 \mathrm{~s}$, there were not yet any clear indications of the long-term stagnation and recession which had unmistakably set in by the early 1620 s. Overseas long-distance trade was buoyant if unpredictable, and while the Dutch access to the east via the 
Cape in 1595 warned of a change of balance to come, the long-standing Spanish and Portuguese positions in the Americas were still secure. New trade openings were being developed at the turn of the century, the optimism that they generated clearly shown in the trading companies and banking facilities springing up in different cities in the first decades of our period. And, whilst the rise in prices had far outstripped that of wages during the sixteenth century, thereby damaging sections of the skilled and unskilled urban populations, there were signs of prosperity both in the older ports of the Mediterranean and in the more recently developing coastal regions of the United Provinces and north-western Germany.

On the political front the outlook seemed particularly good in 1598 . The death of Philip II of Spain, the conclusion of peace with France at Vervins, and the compromise settlement at Nantes of the long and bitter French religious wars all helped to create some ground for optimism. The balance of power in Europe had not shifted significantly. While the Habsburgs clearly dominated Europe with the combined strengths of their Spanish and German imperial branches, neither wing aimed at major aggrandisement within Europe. Emperor Maximilan II had demonstrated his tolerance of (and interest in) Protestantism during the third quarter of the sixteenth century, and while his son and heir Rudolf II was much more encouraging of Counter-Reformation work in the German lands, he progressively lost control of the political situation there. Although the collateral line on the Spanish throne was rigidly and grimly orthodox, it was in no position to use substantial force: the Spanish system was already stretched to capacity to hold its widely scattered European and vast overseas possessions. Apart from the long-standing and now irreconcilable conflict with the rebellious United Provinces in the northern Netherlands, Philip II had also had to face severe threats from the Arab world in the Mediterranean at various times throughout his reign, not to mention the native Morisco population in the Iberian peninsula itself and growing Algiers-based piracy. It was the need to deal with two fronts at once, divided though each was, that prevented Philip II from winning decisively on either. The strain could be observed by anyone in Europe, including the Dutch rebels themselves: most obviously, the financial reputation of the Spanish crown was ruined by recurrent state bankruptcies in 1575, 1596 and 1607. So, while the Spanish position in the Netherlands recovered somewhat in the last years before the twelve year truce of 1609 , and Spain could still call on sizeable resources from for example its Italian possessions, the advisors of Philip III were no doubt correct in their cautious evaluation of long-term prospects.

The first decade of the seventeenth century, therefore, was in some respects a period of recovery from exhaustion on several fronts. As we 
shall note, smouldering religious-based discords in the German lands remained intractable, but in large areas of Europe political and religious stability of a kind had at last been achieved. Both Scandinavian monarchies were under new and effective leadership, and solidly Lutheran. In the British Isles the death of Elizabeth I in 1603 brought a personal union of Scotland and England in the hands of the experienced if eccentric James. In France the reign of Henry IV, later recalled as a 'golden age', very nearly catapulted Europe into another war; but his assassination in 1610 resulted in a cautious regency. East-central and eastern Europe looked less promising, with growing tensions in Bohemia and open confrontation along the Baltic between the Swedish and Polish branches of the Vasa royal family. But there was no immediate risk of these problems overspilling into the rest of Europe, and in the east Muscovy was so torn by internal problems that both Sweden and Poland diverted their attentions in that direction. Conflict in Europe, therefore, was not a foregone conclusion. Initially it even looked as if the Bohemian war of 1618 might produce no sequel, just as many hoped that the 12-year truce between Spain and the United Provinces might be extended indefinitely. Neither turned out to be the case: the Thirty Years War acquired a momentum of its own, which left both the political and the social structure of Europe fundamentally changed. 


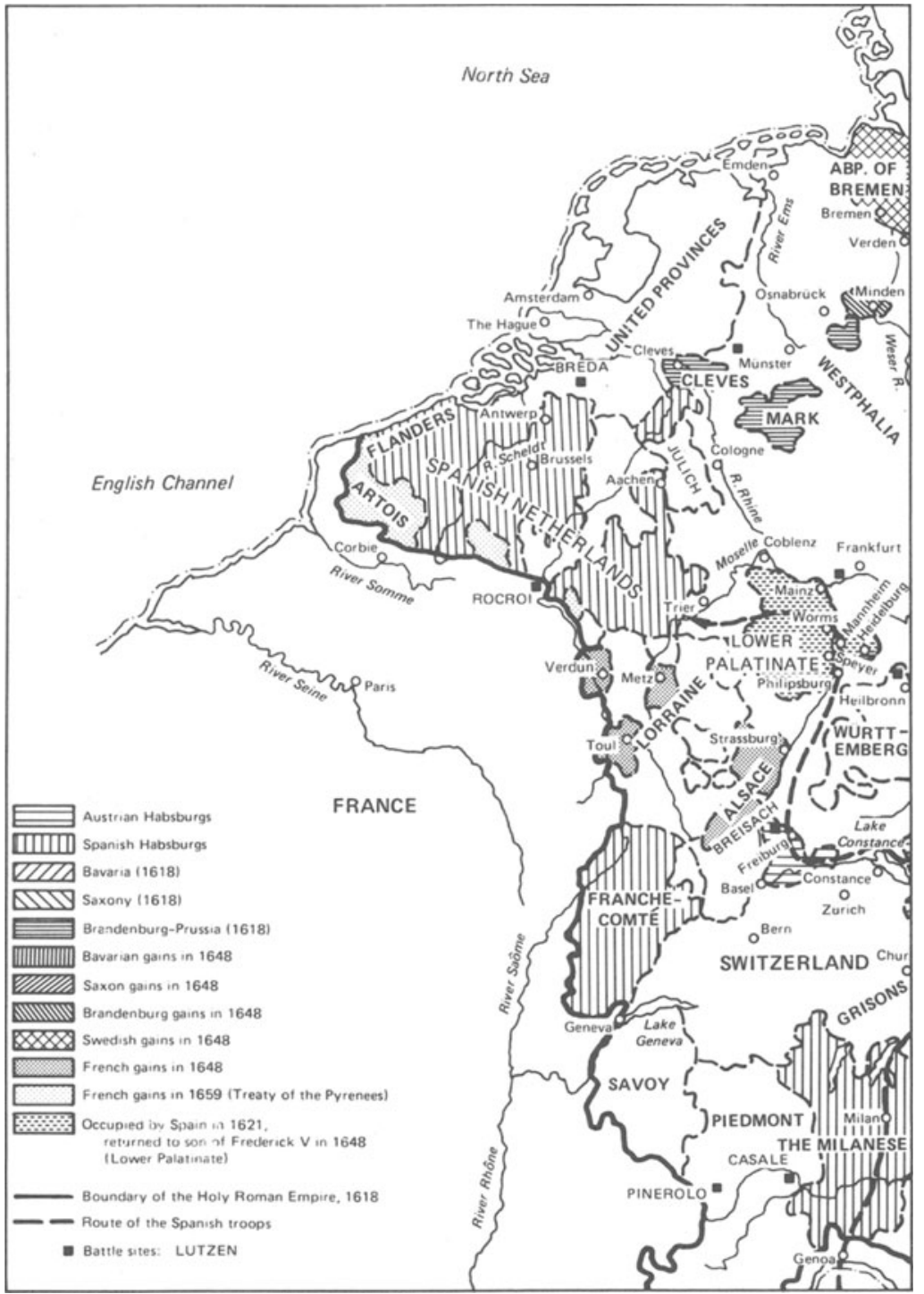

Map 1 The Holy Roman Empire during the Thirty Years War 


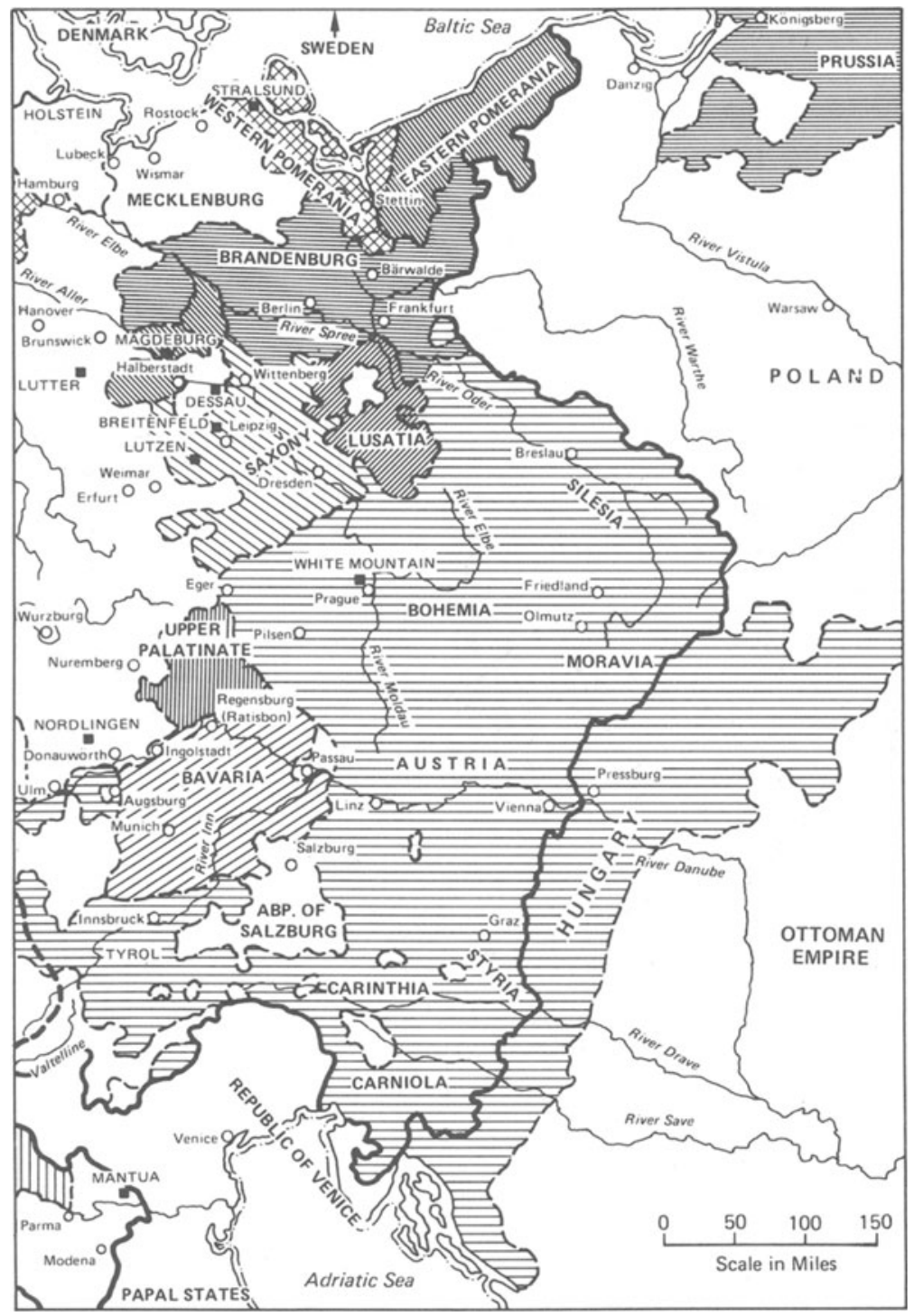



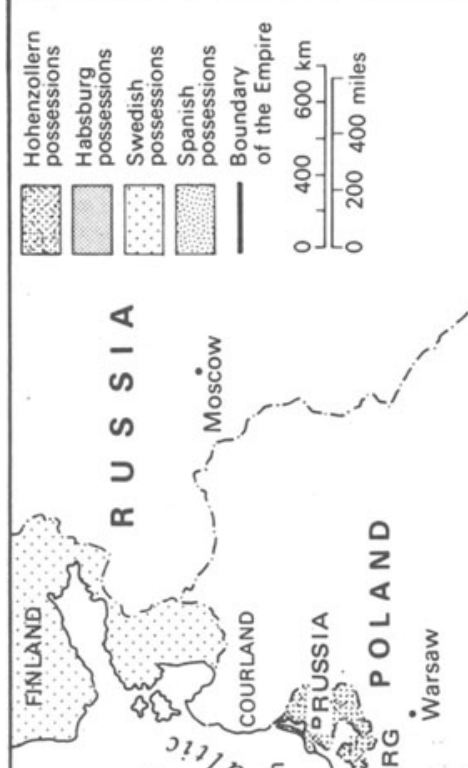

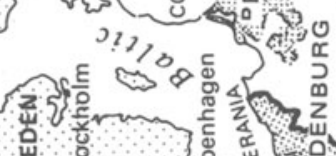

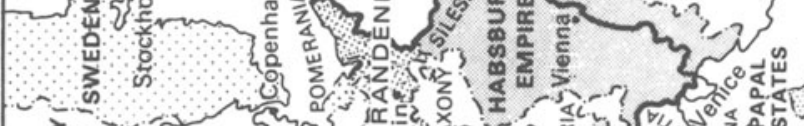

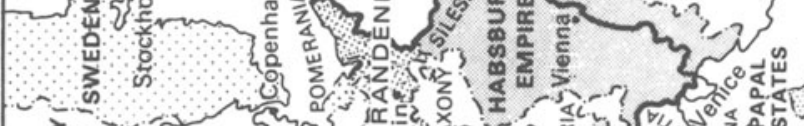

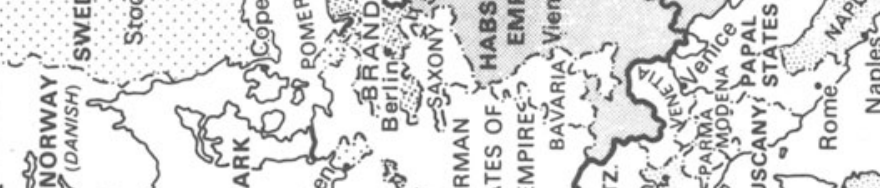

Whon

$+\infty$
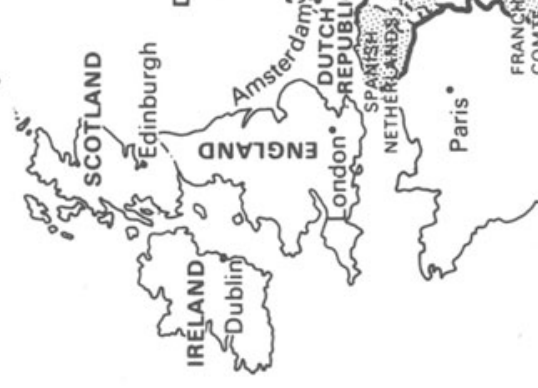

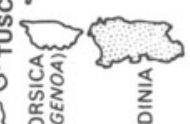
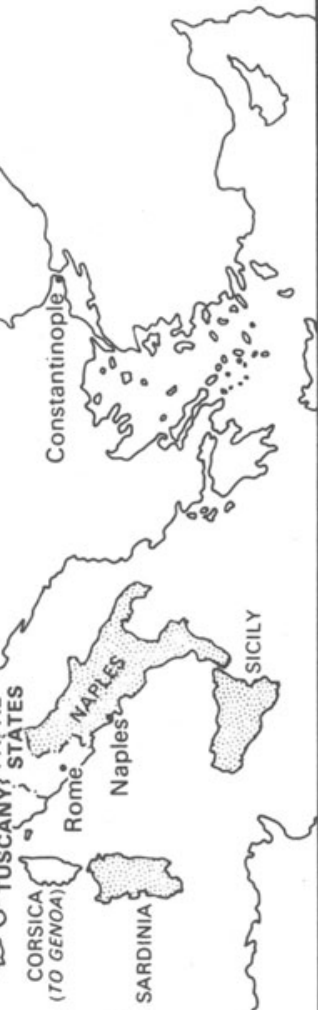